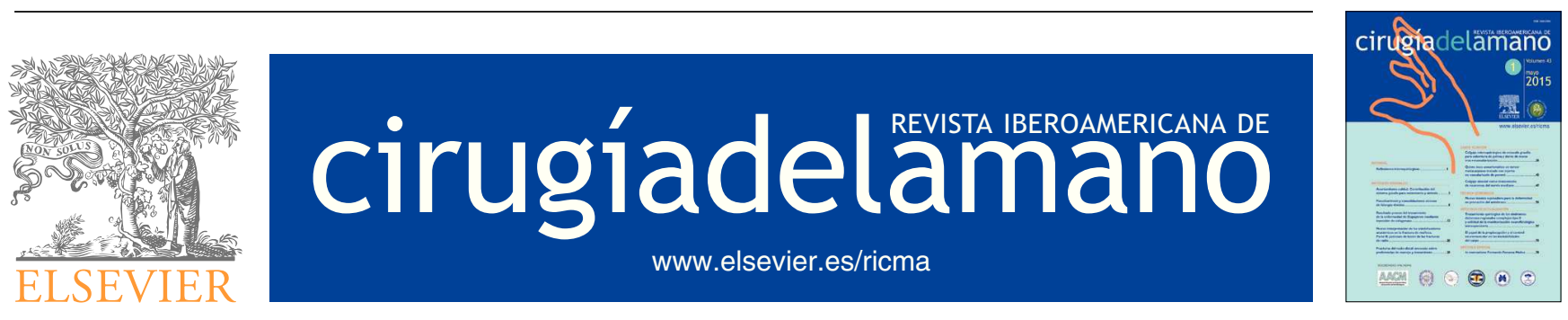

ARTÍCULO ESPECIAL

\title{
In memoriam: Fernando Fonseca Mañez
}

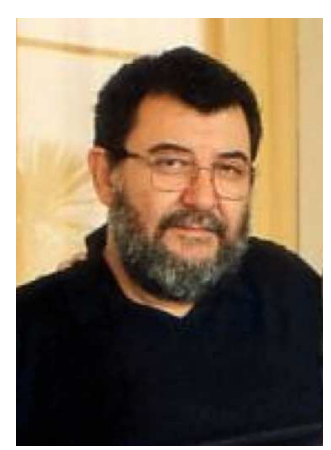

Fernando Fonseca.

Coincidí con Fernando en Barcelona durante mi período de formación como Especialista, en el Instituto Asepeyo (19711974), bajo la tutela del inolvidable maestro Andrés Henríquez. Muy pronto percibí que Fernando era una persona íntegra y un trabajador infatigable. Pese a una presión asistencial elevada, encontramos tiempo para preparar y osadía para publicar nuestros primeros artículos compartidos en la Revista que Asepeyo editaba en aquel entonces. Nunca le abandonó esta pasión por transmitir su experiencia, bajo un prisma de modestia y honestidad ejemplar.

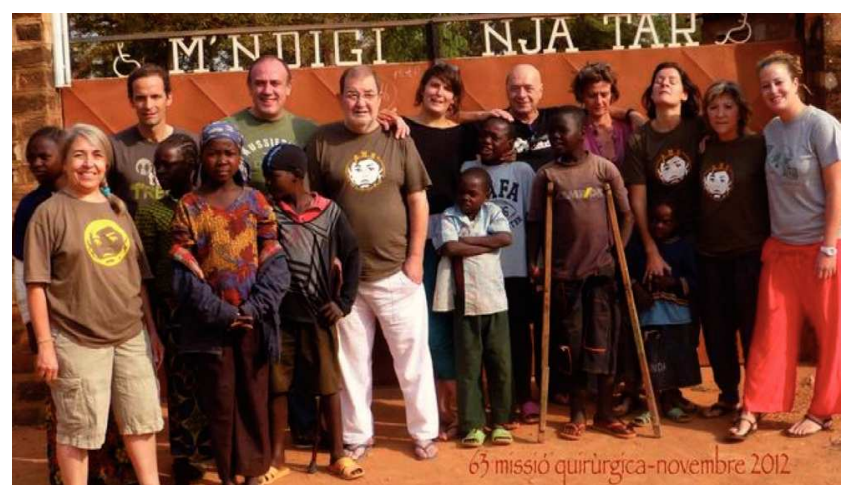

Misión en el CHAD - 2012.
Fernando fue un cirujano de vanguardia, siempre al tanto de los últimos avances de nuestra especialidad, que no dudaba en utilizar, pese a las críticas que le llovían de colegas más conservadores. Su coraje y su habilidad manual, le permitieron salir triunfante del reto de tratar casos de una enorme complejidad. Habitual participante en los Cursos y Congresos de la SECMA, su presencia nunca pasaba desapercibida, y disfrutó de la amistad de la inmensa mayoría de sus socios.

Con Fernando compartí asistencia a múltiples congresos y cursos, el primero en Zaragoza, ciudad a la que viajamos en su viejo Seat 600 , que logró superar a duras penas el puerto del Bruch. Su amistad me la demostró en numerosas ocasiones, entre otras acudiendo desde Barcelona a mi boda en León, ocupándose previamente de reunir las aportaciones de los médicos del Instituto para financiar el regalo de boda, un maletín que conservo con cariño.

De ideales progresistas y buen conocedor de los mentideros políticos, fue un inteligente y feroz crítico de los políticos corruptos, que ya por aquel entonces hacían de las suyas. Desde el inicio de su actividad profesional, puso todo su entusiasmo en ayudar a los más necesitados, dedicando tiempo, salud y dinero a diversas ONG, terminando por tener la suya propia. Muchos colegas han sido testigos de su labor en los países balcánicos, en el Chad y en la República Dominicana. Pude comprobar en el Hospital Darío Contreras (Santo Domingo), el cariño y admiración que le profesaban los colegas dominicanos con los que había colaborado... y por supuesto sus pacientes.

Fue poseedor de un código ético tan exigente como peculiar, lo que le indujo a cuestionar con su característica vehemencia, muchos de los axiomas políticos, profesionales y hasta religiosos que imperaban en nuestro país, probablemente con razón en la mayoría de las ocasiones. Quiero creer que las personas como Fernando tienen que recibir al término de su vida, algún tipo de recompensa por lo que de positivo hicieron durante la misma. Ignoro en qué forma y en qué lugar pueda ser esto posible, pero a cualquiera que sea, te envía un muy fuerte abrazo tu amigo 'Charly', que como todos tus colegas de la SECMA, te echará mucho de menos.

C. Irisarri

* Autor para correspondencia.

Correo electrónico: irisarri@iies.es (C. Irisarri).

( $)$ 2015, SECMA. Publicado por Elsevier España, S.L.U. Este es un artículo Open Acces distribuido bajo los términos de la licencia CC BY-NC-ND (http://creativecommons.org/licenses/by-nc-nd/4.0/). 